\title{
We deserve a government that respects scientific integrity
}

\section{Erin Russell MSc}

$\mathrm{F}$ ederal scientists contribute to the health and safety of Canadians by sharing their knowledge, research and expertise with the public and decision-makers - or so we hope. When the federal government abolished the mandatory long-form census in 2010, replacing it with the voluntary National Household Survey, former chief statistician Munir Sheikh's firm opposition to the decision was presented to the public by then Minister of Industry Tony Clement as support. Only in Dr. Sheikh's public resignation was he able to express his true views. ${ }^{1}$ No one should have to choose between their job and their integrity. Sadly, in recent years, news reports have alleged multiple cases where federal scientists have faced similar ethical dilemmas. ${ }^{2}$

The ability to communicate research is a key pillar of science. The International Committee of Medical Journal Editors warns that, "Authors should avoid entering in to agreements with study sponsors ... that interfere with their ability to analyze and interpret the data and to prepare and publish manuscripts independently when and where they choose." ${ }^{3}$ Yet, in a 2013 survey of federal scientists, 90\% of respondents expressed that they "do not feel that they can speak freely to the media about the work they do." ${ }^{4}$ In addition, 50\% of respondents were "aware of actual cases in which the health and safety of Canadians or environmental sustainability has been compromised because of political interference with their scientific work."

In Prime Minister Stephen Harper's so-called war on science, ${ }^{5}$ we are all casualties. Canada's federal scientists are involved in pharmaceutical regulatory affairs, food inspection, pandemic preparedness and environmental safety among other important areas of research. When public scientists are unable to perform their jobs with integrity, the Canadian public is at risk of ill-informed public policy.

As taxpayers, we support this research only to be denied access to its findings. An economic argument can perhaps be made when making cuts to science and technology at the federal level (cuts estimated at more than $\$ 500$ million between 2008 and 2013), ${ }^{6}$ but keeping scientists on the payroll, while ignoring their advice, is indefensible.

The Professional Institute of the Public Service of Canada (PIPSC) is the largest union representing scientists and professionals employed at federal, provincial and territorial levels of government. ${ }^{7}$ Founded in 1920 to protect the interests of professional public employees, PIPSC became a bargaining agent in 1967. This year marks the first appearance of language about scientific integrity in its collective agreements ${ }^{8}$ and the abandonment of its tradition of political neutrality. ${ }^{9}$ The union has proposed 10 ways to restore Canada's federal public service. These include unmuzzling federal scientists, saving public science and embracing evidence.

That PIPSC has been forced to stand up for scientific integrity is distressing. It should not stand alone on this issue. The nonpartisan, not-for-profit organization Evidence for Democracy $^{2}$ has three ongoing issue-based campaigns, including a science pledge. Federal candidates who take the pledge commit to enacting policies that support science and smart decision-making. At the time of publication, 88 candidates had taken the pledge.

Scientific integrity should be an election issue. Canadian federal scientists need to be free to share their work without political interference. Their union stands behind them, as do many Canadians and a select group of federal candidates. Where do the party leaders stand?

\section{References}

1. Chase S, Grant T. Statistics Canada chief falls on sword over census. Globe and Mail [Toronto] 2010 July 21 [updated 2010 Dec. 22]. Available: www.theglobeandmail. com/news/politics/statistics-canada-chief-falls-on-sword-over-census/article1320915/

2. True North, Smart + Free [homepage]. Ottawa: Evidence for Democracy; 2015. Available: www.truenorthsmartandfree.ca/ (accessed 2015 Aug. 28).

3. Author responsibilities - conflicts of interest. International Committee of Medical Journal Editors; 2015. Available: www.icmje.org/recommendations/browse/roles-and -responsibilities/author-responsibilities--conflicts-of-interest.html (accessed 2015 Aug. 28).

4. The big chill: silencing public interest science, a survey. Ottawa: The Professional Institute of the Public Service of Canada. Available: www.pipsc.ca/portal/page/ portal/website/issues/science/bigchill (accessed 2015 Aug. 28).

5. Turner C. The war on science: muzzled scientists and wilful blindness in Stephen Harper's Canada. Vancouver: Greystone Books; 2013.

6. Vanishing science. Ottawa: The Professional Institute of the Public Service of Canada. Available: www.pipsc.ca/portal/page/portal/website/news/magazine/autumn2014/6 (accessed 2015 Sept. 9).

7. Who we are. Ottawa: The Professional Institute of the Public Service of Canada Available: www.pipsc.ca/portal/page/portal/website/aboutinstitute (accessed 2015 Aug. 28).

8. Semeniuk I. Federal scientists push for protection from political interference. Globe and Mail [Toronto] 2015 May 17. Available: www.theglobeandmail.com/news/national/ federal-scientists-push-for-protection-from-political-interference/article24473222/ (accessed 2015 Aug. 28)

9. Federal scientists and professionals union to campaign against Harper Tories Globe and Mail [Toronto] 2014 Nov. 7. Available: www.theglobeandmail.com/ news/politics/federal-scientists-and-professionals-union-to-campaign-against-harper -tories/article21512063/ (accessed 2015 Aug. 28).

Competing interests: See www.cmaj.ca/site/misc/cmaj_staff.xhtml

Affiliation: Assistant Editor, $C M A J$

Correspondence to: CMAJ editor,pubs@cmaj.ca

CMAJ 2015. DOI:10.1503/cmaj.151006 